\title{
HUBUNGAN BODY IMAGE, ASOSIASI EMOSIONAL, DAN POLA KONSUMSI DENGAN STATUS ANEMIA PRAMUGARI
}

\author{
Relationship between Body image, Emotional Association and Consumption Pattern with Anemia \\ Status of Stewardess \\ Khaulah Ali Badjree ${ }^{1}$, Lailatul Muniroh ${ }^{2}$ \\ ${ }^{1}$ Program Studi S1 Ilmu Gizi, Fakultas Kesehatan Masyarakat, Universitas Airlangga, Surabaya \\ ${ }^{2}$ Departemen Gizi Kesehatan, Fakultas Kesehatan Masyarakat, Universitas Airlangga, Surabaya \\ Email: khaulabajry@gmail.com
}

\begin{abstract}
ABSTRAK
Pramugari merupakan salah satu profesi yang sangat memperhatikan bentuk tubuh dan pola makannya. Pramugari membutuhkan gizi yang cukup untuk menjalankan aktifitasnya. Beberapa gizi yang dibutuhkan adalah zat besi, asam folat dan vitamin B12 agar dapat terhiNdar dari anemia. Konsumsi makanan tersebut dapat dipengaruhi oleh beberapa hal salah satunya adalah ada tidaknya pengaruh emosi dalam pemilihan makanan. Tujuan dari penelitian ini adalah menganalisis hubungan body image, asosiasi emosional dan pola konsumsi dengan status anemia pramugari. Penelitian ini menggunakan desain cross sectional. Besar sampel menggunakan rule of thumb dan diperoleh sebanyak 37 pramugari. Analisis hubungan pada variabel dalam penelitian ini menggunakan uji chi-square, korelasi spearman dan korelasi pearson. Hasil penelitian menunjukkan sebagian besar pramugari memiliki body image yang negatif dan asosiasi emosional yang menunjukkan bahwa mereka terpengaruh dengan emosinya. Pramugari yang menderita anemia sebanyak 45,9\%. Penelitian ini menunjukkan terdapat hubungan antara body image $(p=0,003)$ dan asosiasi emosional ( $p=0,001)$ dengan status anemia pramugari. Tidak ada hubungan antara pola konsumsi sumber Fe, asam folat, vitamin B12 $(p=0,314)$, dan inhibitor $(p=0,921)$ dengan status anemia pramugari. Kesimpulan dalam penelitian ini adalah sebagian besar pramugari cenderung mengalami anemia bila memiliki body image negatif dan terdapat pengaruh emosi dalam pemilihan makanan yang dikonsumsi kesehariannya. Saran yang dapat diberikan agar pramugari dapat mengontrol emosinya terutama yang terkait dengan pola konsumsinya dan mengubah pola pikir terkait body image yang negatif.
\end{abstract}

Kata kunci: asosiasi emosional, body image, pramugari, status anemia

\begin{abstract}
A stewardess is one of the professions that pay attention to body shape and diet. A stewardess need enough nutrition to do their activities. Suxh as iron, folic acid, and vitamin $B 12$ to prevent them from anemia. Consumption of these foods can be influenced by several things one of them is the presence or absence of emotional influence in the food selection. The purpose of this research was to analyze the relationship of body image, emotional association and consumption pattern with anemia status of stewardess. This study used a cross-sectional design. Sample size using rule of thumb and obtained 37 respondents. Relationship analysis on the variables in this study using chi-square, spearman correlation and pearson correlation. The results of this study showed that most stewardess having negative body image and emotional association who was emotionally affected. A stewardess who suffer from anemia as much 45.9\%. This research showed that there was a relationship between body image $(p=0.003)$ and emotional association $(p=0.001)$ with anemia status of the stewardess, whereas the consumption patterns of Fe, folic acid, vitamin B12 ( $p=0.314)$ and inhibitors $(p=0.921)$ didn't correlate with anemic status of stewardess. The conclusion in this study is that most stewardess tend to have anemia if they have a negative body image and there is an emotional influence in the selection of food consumed in daily life. Suggestions that can be given so that stewardess can control their emotions in their dietary needs and also change the mindset of negative body image to be fit for health.
\end{abstract}

Keywords: emotional association, body image, stewardess, anemia status 


\section{PENDAHULUAN}

Anemia merupakan suatu kondisi jumlah sel darah atau kapasitas oksigen tidak cukup memenuhi kebutuhan fisiologis (WHO, 2011). Menurut Khaidir (2007) anemia merupakan masalah gizi di seluruh negara maju dan berkembang. Prevalensi anemia di Indonesia paling tinggi dialami oleh wanita yakni 23,9\% (Balitbangkes, 2013). Salah satu penyebab terjadinya anemia adalah rendahnya konsumsi makanan yang mengandung zat besi, asam folat, vitamin B12 dan vitamin A (WHO, 2011). Hal tersebut sesuai dengan penelitian Noviawati (2015) yang menyatakan bahwa 67,4\% mahasiswi yang diteliti mengalami asupan Fe rendah dan $69,4 \%$ diantaranya mengalami anemia.

Kurangnya konsumsi zat besi, asam folat, vitamin B12 serta enhancer merupakan salah satu hasil dari pola konsumsi seseorang yang kurang baik. Menurut Setyaningsih (2015) sebanyak 94,81\% wanita hamil yang mengalami anemia memiliki pola konsumsi sumber Fe yang kurang dalam kesehariannya. Pola konsumsi dalam keseharian dipengaruhi oleh kebiasaan makan individu. Kebiasaan makan merupakan cara individu dan kelompok dalam memilih, mengonsumsi, dan menggunakan makanan yang tersedia dengan didasarkan kepada faktorfaktor dimana mereka hidup (Arisman, 2004). Salah satu faktor yang mempengaruhi kebiasaan makan seseorang adalah faktor intrinsik. Faktor intrinsik merupakan faktor yang berasal dari dalam diri manusia. Faktor intrinsik kebiasaan makan seseorang meliputi asosiasi emosional, keadaan jasmani, dan penilaian yang lebih terhadap makanan. Asosiasi emosional merupakan pengaruh perasaan dalam pemilihan makanan (Dovey, 2010). Salah satu contohnya adalah keadaan sedih yang dialami seseorang akan mengurangi nafsu makannya hingga perasaan itu berakhir.

Menurut penelitian Amissah, dkk. (2015) kebiasaan makan mahasiswa dipengaruhi oleh kesehatan psikologis dan body image. Hasil penelitian tersebut saling mempengaruhi satu sama lain. Body image lebih mempengaruhi kebiasaan makan dari pada kesehatan psikologis mahasiswa.
Persepsi terhadap bentuk tubuh mereka sendiri dan memikirkan tanggapan orang lain tentang tubuh mereka merupakan pengertian dari body image (NEDC, 2016). Menurut Brennan, et al. (2010) ketidakpuasan terhadap bentuk tubuh lebih banyak dialami oleh wanita dibandingkan dengan pria

Body image akan memicu wanita untuk memperbaiki penampilan mereka. Semakin positif body image yang dimiliki wanita maka perilaku untuk memperbaiki penampilan mereka semakin rendah (Husna, 2013). Memperbaiki penampilan yang biasa dilakukan wanita adalah melakukan aktifitas lebih, mengubah asupan makan, berolahraga, meminum suplemen penurun atau penaik berat badan, dan lain sebagainya. Salah satu keadaan yang menyebabkan seseorang mencapai body image yang diinginkan adalah profesi. Menurut Amalia (2014) seluruh model yang diteliti merasa tidak puas terhadap bentuk tubuhnya, dan sebagian besar mengubah pola konsumsinya untuk mencapai body image yang diinginkan.

Pramugari merupakan salah satu profesi yang juga memperhatikan penampilan fisik. Menurut Patricia (2014) seorang pramugari merupakan front liner dan brand image dari suatu maskapai. Oleh karena itu pramugari dituntut untuk menjaga penampilan, attitude, dan bertutur kata yang baik kepada siapa saja terutama pelanggan. Profesi sebagai pramugari dapat mengubah cara pandang mereka terhadap penampilan fisik mereka. Penampilan fisik yang harus dimiliki oleh pramugari adalah postur tubuh yang proporsional dan berat badan ideal (Putri, 2014). Tuntutan tersebut membuat seorang pramugari merasa stress dengan keadaan tubuh mereka dan dapat mengganggu keadaan emosional serta dapat mengubah pola konsumsi mereka dari kebiasaan. Bila hal tersebut dilakukan secara berlebihan akan membuat pramugari memiliki body image yang negatif.

Penelitian ini bertujuan menganalisis hubungan body image, asosiasi emosional, dan pola konsumsi dengan status anemia yang dialami oleh pramugari di salah satu maskapai yang ada di Indonesia. Pola konsumsi yang diteliti merupakan konsumsi sumber makanan zat besi, asam folat, vitamin B12 dan sumber makanan inhibitor yakni tanin (kopi dan teh). 


\section{METODE}

Penelitian ini merupakan jenis penelitian analitik observasional dengan menggunakan desain penelitian cross sectional. Penelitian ini dilaksanakan dari bulan Maret hingga Juni 2017 di kantor salah satu maskapai di Kota Surabaya. Populasi dari penelitian ini adalah pramugari dari salah satu maskapai di Indonesia. Penentuan besar sampel dalam penelitian ini menggunakan teknik Rule of thumb milik Roscoe (Sugiyono, 2009). Sampel yang didapat antara 30-500 dalam kurun waktu yang telah ditentukan oleh peneliti dan pihak maskapai. Penentuan sampel menggunakan teknik accidental sampling, yaitu pramugari yang sedang berada di kantor maskapai dan bersedia menjadi responden. Selama penelitian berlangsung sebanyak 37 pramugari yang dapat diteliti.

Pengambilan data karakteristik responden, body image, asosiasi emosional, dan pola konsumsi dilakukan dengan wawancara menggunakan kuesioner. Pengambilan data kadar $\mathrm{Hb}$ responden dilakukan dengan menggunakan alat portable bermerek Easytouch $\mathrm{GCHb}$ yang dilakukan oleh analis medis terlatih. Karakteristik responden meliputi usia, lama bekerja dan pendapatan responden. Pengukuran body image menggunakan kuesioner Body Shape Questionnaire (BSQ) yang diadopsi dari Cooper, et al. (1986) dengan jumlah 16 pernyataan. Setiap pernyataan akan dinilai 1 hingga 6 dengan penjelasan tidak pernah hingga selalu. Pengukuran asosiasi emosional responden menggunakan kuesioner yang diadopsi dari Ozier, et al. (2007) yakni The Eating and Appraisal Due to Emotions and Stress (EADES) dengan jumlah 24 pertanyaan. Pola konsumsi yang diteliti adalah frekuensi responden dalam mengonsumsi makanan sumber zat besi, asam folat, vitamin B12 dan sumber inhibitor, pengukurannya menggunakan form Food Frequency Questionnaire (FFQ).

Hasil penelitian disajikan dalam distribusi frekuensi dan tabulasi silang. Analisis statistik dalam penelitian ini menggunakan uji chi-square, uji korelasi spearman dan korelasi pearson. Uji chi-square digunakan untuk data nominal seperti pola konsumsi. Korelasi spearman digunakan untuk data dengan skala ordinal seperti asosiasi emosional. Korelasi pearson digunakan untuk data rasio seperti body image. Penelitian ini telah lulus uji etik dari Komisi Etik Penelitian Kesehatan Masyarakat Universitas Airlangga dengan nomor sertifikat 225-KEPK.

\section{HASIL DAN PEMBAHASAN}

Karakteristik responden yang didapat menggambarkan bahwa usia responden paling banyak berkisar 19-29 tahun. Menurut indepth interview kepada sebagian responden menyatakan bahwa pramugari yang berusia diatas 30 tahun telah mengurangi waktunya di maskapai karena urusan keluarga dan juga usaha lain. Pada penelitian Sary, dkk. (2014) menunjukkan juga bahwa sebagian besar pramugari yang diteliti berusia antara 18 hingga 29 tahun.

Menurut data yang didapat rata-rata lama bekerja pramugari di salah satu maskapai di Indonesia berkisar 3,5 tahun. Hasil penelitian menggambarkan bahwa sebagian besar responden telah bekerja diatas 3,5 tahun. Lama bekerjanya pramugari di suatu maskapai tidak mempengaruhi pendapatan mereka. Pendapatan pramugari ditentukan oleh tinggi rendahnya jam terbang mereka. Semakin padat jam terbang maka semakin tinggi pendapatan mereka. Karakteristik responden di jelaskan pada Tabel 1.

Tabel 1. Karakteristik Responden Mengenai Usia, Lama Bekerja, dan Pendapatan

\begin{tabular}{lcc}
\hline \multicolumn{1}{c}{ Karakteristik } & $\mathbf{n}$ & $\mathbf{\%}$ \\
\hline Usia & & \\
19-29 tahun & 28 & 75,7 \\
30-45 tahun & 9 & 24,3 \\
Lama Bekerja & & \\
$\quad<3,5$ tahun & 18 & 48,6 \\
$\geq 3,5$ tahun & 19 & 51,4 \\
Pendapatan & & \\
$<11.400 .000$ & 16 & 43,2 \\
$\geq 11.40 .000$ & 21 & 56,8 \\
\hline
\end{tabular}

Pendapatan pramugari dikelompokan menurut rata-rata yang didapat saat wawancara berlangsung. Rata-rata pendapatan pramugari sebesar $\mathrm{Rp}$. 11.400.000 setiap bulannya. Menurut Tabel 1 sebagian besar pramugari yang diteliti memiliki pendapatan diatas rata-rata. Hal tersebut sesuai dengan Pusporiny (2016) yang menyatakan bahwa 
pendapatan seorang pramugari berkisar antara 10 hingga 20 juta rupiah setiap bulannya. Sebagian besar pendapatan yang didapat oleh pramugari dihabiskan untuk memenuhi kebutuhan hidupnya sehari-hari dan keluarga mereka di daerah asal.

Lebih dari separuh $(54,1 \%)$ pramugari tidak mengalami anemia dan memiliki body image yang negatif serta adanya pengaruh emosi dalam kebiasaan makan mereka. Berdasarkan indepth interview kepada manager di salah satu maskapai, pramugari melakukan pemeriksaan rutin terkait kesehatan dan komposisi tubuh. Pramugari yang sedang sakit disarankan untuk beristirahat hingga pulih, sedangkan pramugari yang komposisi tubuhnya melebihi standar yang ditentukan oleh pihak maskapai maka disarankan untuk menurunkan berat badan. Keadaan tersebut dapat mempengaruhi body image pramugari. Perasaan dan perilaku yang berlebihan dalam memersepsikan bentuk tubuh dapat membuat mereka memiliki body image yang negatif. Hasil penelitian Amalia (2014) menunjukkan bahwa seluruh model yang diteliti merasa tidak puas akan bentuk tubuhnya.

Tabel 2. Distribusi Anemia, Body Image, dan Asosiasi Emosi

\begin{tabular}{|c|c|c|}
\hline Karakteristik & $\mathrm{n}$ & $\%$ \\
\hline \multicolumn{3}{|l|}{ Anemia } \\
\hline$<12 \mathrm{mg} / \mathrm{dl}$ & 17 & 45,9 \\
\hline$\geq 12 \mathrm{mg} / \mathrm{dl}$ & 20 & 54,1 \\
\hline Mean \pm SD & \multicolumn{2}{|c|}{$11,995 \pm 1,152$} \\
\hline \multicolumn{3}{|l|}{ Body Image } \\
\hline Positif & 11 & 29,7 \\
\hline Negatif & 26 & 70,3 \\
\hline Mean \pm SD & \multicolumn{2}{|c|}{$48,35 \pm 16,623$} \\
\hline \multicolumn{3}{|l|}{ Asosiasi emosional } \\
\hline Tidak terpengaruh emosi & 18 & 48,6 \\
\hline Terpengaruh emosi & 19 & 51,4 \\
\hline Mean $\pm \mathrm{SD}$ & \multicolumn{2}{|c|}{$55,14 \pm 5,034$} \\
\hline
\end{tabular}

Pada Tabel 2 menunjukkan sebanyak 45,9\% pramugari menderita anemia. Pada variabel body image, sebagian besar pramugari memiliki persepsi yang negatif. Tidak hanya itu, sebagian besar pramugari memiliki asosiasi yang dipengaruhi oleh emosionalnya, hal tersebut menjelaskan bahwa pada saat memilih makan pramugari akan melibatkan emosinya.

Keadaan body image yang negatif pada pramugari dapat mempengaruhi kesehatan pramugari salah satunya adalah mengalami anemia. Penelitian ini menggambarkan bahwa sebagian besar pramugari yang mengalami anemia memiliki body image yang negatif. Data distribusi karakteristik responden dan hubungan body image dengan status anemia pramugari tahun 2017 digambarkan pada Tabel 2 dan 3.

Tabel 3. Hubungan Body Image dengan Status Anemia

\begin{tabular}{|c|c|c|c|c|c|c|}
\hline \multirow{2}{*}{ Body Image } & \multicolumn{2}{|c|}{ Anemia } & \multicolumn{2}{|c|}{ Tidak Anemia } & \multirow{2}{*}{$\mathbf{r}$} & \multirow[b]{2}{*}{ p } \\
\hline & $\mathrm{n}$ & $\%$ & $n$ & $\%$ & & \\
\hline Negatif & 17 & 45,9 & 9 & 24,3 & \multirow{2}{*}{0,468} & \multirow{2}{*}{0,003} \\
\hline Positif & 0 & 0 & 11 & 29,7 & & \\
\hline
\end{tabular}

Tabel 3 menjelaskan bahwa terdapat hubungan antara body image dan status anemia pramugari. Hal tersebut sesuai dengan penelitian Amalia (2014) yang menyatakan bahwa $56,9 \%$ wanita yang mengalami body image negatif mengalami anemia. Keadaan tersebut dapat mempengaruhi kebiasaan makan mereka. Penelitian Amalia (2014) menyatakan bahwa $42,9 \%$ wanita yang memiliki body image negatif melakukan perilaku diet yang kurang baik dan hal tersebut dapat mempengaruhi status anemianya.

Status anemia seseorang tidak hanya dipengaruhi oleh body image dari seseorang. Menurut National Heart, Lung, and Blood Institute (NHLBI) (2012) salah satu penyebab terjadinya anemia pada seseorang adalah kebiasaan makan. Salah satu yang mempengaruhi kebiasaan makannya adalah keadaan emosional dari orang tersebut.

Menurut Dovey (2010) terdapat beberapa orang yang meningkatkan konsumsi makanan dan gula ketika suasana hati yang tidak menentu. Hal tersebut terjadi pada pramugari. Sebanyak $51,4 \%$ pramugari memiliki asosiasi emosional yang positif. Hasil tersebut menunjukkan bahwa pramugari akan mengubah kebiasaan makan mereka ketika keadaan emosionalnya sedang tidak stabil. Salah satu keadaan emosi yang tidak stabil adalah stres dan pemicunya adalah beban 
Tabel 4. Hubungan antara Asosiasi Emosional dengan Status Anemia

\begin{tabular}{|c|c|c|c|c|c|c|}
\hline \multirow{2}{*}{ Asosiasi Emosional } & \multicolumn{2}{|c|}{ Anemia } & \multicolumn{2}{|c|}{ Tidak Anemia } & \multirow{2}{*}{$\mathbf{r}$} & \multirow{2}{*}{$\mathbf{p}$} \\
\hline & $\mathbf{n}$ & $\%$ & $\mathbf{n}$ & $\%$ & & \\
\hline Tidak terpengaruh emosi (asosiasi emosional negatif) & 6 & 16,2 & 12 & 32,4 & \multirow{2}{*}{0,524} & \multirow{2}{*}{0,001} \\
\hline Terpengaruh emosi (asosiasi emosional positif) & 11 & 29,8 & 8 & 21,6 & & \\
\hline
\end{tabular}

kerja yang dimiliki. Menurut penelitian Junaidi (2015) sebanyak $51,1 \%$ pegawai BPPKB Sulawesi Tengah memiliki beban kerja yang sangat tinggi dan $93,6 \%$ diantaranya mengalami stress akibat kerja mereka.

Hasil penelitian Fassah dan Retnowati (2014) menjelaskan emotional distress yang dialami mahasiswa baru di UGM menyumbangkan 8,3\% perilaku makan yang tidak sehat kepada dirinya sendiri. Keadaan emosional yang mengubah kebiasaan makan pramugari dapat menyebabkan terjadinya anemia pada mereka.

Tabel 4 menjelaskan bahwa angka signifikan dari korelasi spearman antara asosiasi emosional dan status anemia pramugari adalah 0,001 . Hasil tersebut menggambarkan bahwa terdapat hubungan antara asosiasi emosional dengan status anemia pramugari. Sebanyak $51,4 \%$ pramugari yang memiliki asosiasi emosional positif $29,8 \%$ diantaranya mengalami anemia. Penelitian Cvetovac dan Hamar (2012) menyatakan bahwa responden dengan emosi yang tidak stabil akan membuat mereka mengonsumsi makanan yang tidak sehat. Hal tersebut dapat terjadi pada pramugari, keadaan emosi yang tidak stabil membuat mereka mengonsumsi makanan atau minuman yang membuat mereka merasa relaks salah satunya adalah minuman yang mengandung tanin yakni teh. Sebagian besar dari mereka bila merasakan stress yang cukup berat akan mengurangi makan mereka dan hal tersebut dapat menjadi salah satu pemicu terjadinya anemia.

Penelitian ini memperlihatkan pola konsumsi pramugari mengenai jenis makanan sumber zat besi, asam folat, vitamin B12 dan inhibitornya yakni teh dan kopi. Berdasarkan indepth interview bahwa pada saat penerbangan mereka mendapatkan konsumsi dari pihak maskapai, namun pada saat day off mereka lebih suka mengonsumsi makanan instan seperti mie instan. Alasan mereka mengonsumsi mie instan dikarenakan makanan tersebut praktis dan mudah disimpan sehingga mereka tidak perlu keluar untuk mencari makan pada saat di tempat kos.

Pola konsumsi sebagian besar pramugari untuk jenis makanan sumber zat besi, asam folat dan vitamin B12 termasuk dalam kategori kadangkadang. Hal tersebut menggambarkan bahwa frekuensi pramugari mengonsumsi jenis makanan sumber zat besi, asam folat dan vitamin B12 1-3 kali dalam seminggu. Jenis makanan yang sering dikonsumsi dalam hitungan minggu adalah daging sapi. Menurut Sary, dkk. (2014) sebanyak 72,4\% pramugari mengonsumsi kurang dari 3 kali dalam seminggu untuk jenis makanan daging sapi. Jenis makanan sumber zat besi, asam folat, vitamin

Tabel 5. Hubungan Pola Konsumsi Sumber Zat Besi, Asam Folat, Vitamin B12 dan Inhibitor dengan Status Anemia Pramugari

\begin{tabular}{|c|c|c|c|c|c|}
\hline \multirow{2}{*}{ Kategori } & \multicolumn{2}{|c|}{ Anemia } & \multicolumn{2}{|c|}{ Tidak Anemia } & \multirow{2}{*}{$\mathbf{p}$} \\
\hline & n & $\%$ & $\mathbf{n}$ & $\%$ & \\
\hline \multicolumn{6}{|c|}{ Sumber zat besi, asam folat dan Vitamin B12 } \\
\hline Sering & 5 & 13,5 & 5 & 13,5 & \\
\hline Kadang-kadang & 8 & 21,6 & 6 & 16,2 & 0,314 \\
\hline Jarang & 4 & 10,8 & 9 & 24,3 & \\
\hline \multicolumn{6}{|l|}{ Sumber inhibitor } \\
\hline Sering & 9 & 24,3 & 11 & 29,7 & \\
\hline Kadang-kadang & 5 & 13,5 & 4 & 10,8 & 0,921 \\
\hline Jarang & 3 & 8,1 & 5 & 13,5 & \\
\hline
\end{tabular}


B12 yang jarang atau tidak pernah dikonsumsi oleh sebagian besar pramugari adalah udang dan hati sapi. Udang merupakan makanan yang dimakan 1-2 kali dalam sebulan oleh sebagian besar pramugari karena harga yang cukup mahal dan sulit ditemukan di daerah mereka tinggal di Surabaya. Sebagian besar pramugari tidak mengonsumsi hati sapi dengan alasan tidak suka dan juga jarang ditemukan di daerah mereka.

Frekuensi sebagian besar pramugari dalam mengonsumsi sumber inhibitor termasuk dalam kategori sering. Sebanyak $54,1 \%$ pramugari mengonsumsi makanan sumber inhibitor dalam setiap harinya. Sebagian besar sumber inhibitor yang dikonsumsi pramugari adalah teh. Sebanyak $32,4 \%$ pramugari mengonsumsi teh lebih dari satu kali dalam sehari dan waktu mengonsumsinya pada saat setelah makan.

Hasil penelitian Sary, dkk. (2014) sebanyak $53,2 \%$ pramugari mengonsumsi teh pada saat setelah makan. Pramugari mengonsumsi teh pada saat makan memiliki risiko 1,2 kali lebih tinggi untuk terkena anemia dari pada pramugari yang tidak mengonsumsi teh sama sekali atau tidak pada saat makan. Hubungan pola konsumsi sumber zat besi, asam folat, vitamin B12 dan inhibitor dengan status anemia pramugari digambarkan pada Tabel 5. Hasil dari Tabel 5 menggambarkan bahwa tidak ada hubungan antara pola konsumsi sumber zat besi, asam folat, vitamin B12 dan inhibitor dengan status anemia pramugari. Pramugari yang paling banyak mengalami anemia adalah pramugari yang pola konsumsi sumber zat besi, asam folat dan vitamin B12 termasuk dalam kategori kadang-kadang. Penelitian Sary, dkk. (2014) menggambarkan tidak ada hubungan antara konsumsi daging sapi setiap minggu dengan anemia pramugari, namun pramugari yang mengonsumsi daging sapi lebih dari 3 kali dalam seminggu memiliki risiko $43 \%$ lebih kecil untuk mengalami anemia.

Pola konsumsi sumber inhibitor baik pada pramugari yang mengalami anemia ataupun tidak, mayoritas berada dalam kategori sering. Tabel 5 menunjukkan bahwa pramugari yang sering mengonsumsi sumber inhibitor paling banyak mengalami anemia dibandingkan dengan pramugari yang kadang maupun jarang mengonsumsi sumber inhibitor. Salah satu pemicu terjadinya anemia adalah waktu dalam mengonsumsi sumber inhibitor. Mengonsumsi sumber inhibitor pada saat makan dapat menghambat penyerapan makanan sumber zat besi, asam folat, vitamin B12. Menurut Fitri (2016) pekerja wanita memiliki risiko tinggi menderita anemia bila mengonsumsi teh pada saat setelah makan. Sebanyak 55\% pekerja wanita di PT. Indah Kiat Pulp and Paper mengonsumsi teh cukup sering dan $50 \%$ diantaranya mengalami anemia. Penelitian ini juga menggambarkan bahwa mengonsumsi sumber inhibitor dapat meningkatkan risiko menderita anemia, walaupun pola konsumsi sumber inhibitor dan status anemia pramugari tidak berhubungan.

\section{KESIMPULAN DAN SARAN}

Sebagian besar pramugari yang memiliki body image negatif dan asosiasi emosional yang positif cenderung mengalami anemia. Pramugari termasuk dalam kategori kadang-kadang dalam mengonsumsi sumber zat besi, asam folat dan vitamin B12, sementara konsumsi sumber inhibitor, dalam kategori sering. Pola konsumsi sumber zat besi, asam folat, vitamin B12 dan inhibitor tidak berhubungan dengan status anemia pramugari.

Saran untuk responden adalah dapat melatih diri untuk tetap mengontrol makanan mereka dalam keadaan emosi yang berubah-ubah. Pramugari juga dapat mengubah pola pikir terkait body image yang negatif menjadi body image yang sesuai standar kesehatan. Pramugari juga dapat meningkatkan konsumsi sumber zat besi, asam folat, dan vitamin B12 serta mengurangi konsumsi sumber inhibitor setelah makan.

\section{DAFTAR PUSTAKA.}

Amalia, M. (2014). Hubungan body image dengan perilaku diet dan kadar hb pada remaja putri di SMAN 10 Kota Makasar (Skripsi, Universitas Hasanuddin, Makasar). Diakses dari http://repository.unhas.ac.id/ bitstream/handle/123456789/10474/ MARINI\%20AMALIA\%20M\%20K21110108. pdf? sequence $=1$.

Amalia, R. (2014). Body image, tindakan membatasi asupan makan, dan status gizi model remaja putri 
di Surabaya (Skripsi, Universitas Airlangga, Surabaya). Diakses dari http://repository.unair. ac.id/23872/2/FULLTEXT.pdf.

Amissah,C.M., Nyarko, K., Gyasi-gyamera, \& A., Winne,M.N. (2015). Relationships among body image, eating behaviour, and psychological health of University of Ghana Students. International Journal of Humanities and Social Science, 5(6), 192-203. Diakses dari http:// www.ijhssnet.com/journals/Vol_5_No_6_ June_2015/23.pdf.

Arisman. (2004). Gizi dalam daur kehidupan. Jakarta: CBC.

Balitbangkes. (2013). Riset kesehatan dasar Tahun 2013. Diakses dari http://www.depkes. go.id/resources/download/general/Hasil\%20 Riskesdas\%202013.pdf.

Brennan, M.A., Lalonde, C.E., \& Bain, J.L. (2010). Body image perceptions : Do gender differences exist. Journal of Undergraduate Research, 15(3), 130-138. Diakses dari http://web.uvic. ca/ lalonde/manuscripts/2010-Body\%20Image. pdf.

Cooper, P.J., Taylor,M.J. Cooper,Z., \& Fairburn, C.G. (1986). The development and validation of the body shape questionner. International Journal of Eating Disorders, 6(4), 485-494. Diakses dari http://onlinelibrary.wiley.com/ doi/10.1002/1098-108X(198707)6:4\%3C485 ::AIDAT2260060405\%3E3.0.CO;2/epdf?r3 referer $=$ wol\&tracking_action $=$ preview click\&show_checkout $=1 \&$ purchase referrer=www.google.co.id\&purchase_site license $=$ LICENSE DENIED.

Cvetovac, M., \& Hamar, S. (2012). Stress and unhealthy eating in a collage sample. Paper presented at The National Conference On Undergraduate Research (NCUR), Ogden Utah. Diakses dari http://www.ncurproceedings. org/ojs/index.php/NCUR2012/article/ view/185/161.

Dovey, T.,M. (2010). Eating behaviour. New York: Open University Pers.

Fassah, D.R. \& Retnowati, S. (2014). Hubungan antara emotional distress dengan perilaku makan tidak sehat pada mahasiswa baru. Jurnal Psikologi, 10 (1), 11-17. Diakses dari http:// ejournal.uin-suska.ac.id/index.php/psikologi/ article/view/1174/1066.

Fitri, L. (2016). Hubungan Pola Makanan dengan Anemia pada Pekerja Wanita di PT. Indah Kilat
Pulp and Paper (IKPP) tbk. Perawang. Journal Endurance, 1(3), 152-157.

Khaidir, M. (2007). Anemia defisiensi besi. Jurnal Kesehatan Masyarakat Andalas, 2(1), 140-145. Diakses dari http://jurnal.fkm.unand.ac.id/ index.php/jkma/article/view/23

Husna, N.L. (2013). Hubungan antara body image dengan perilaku diet (penelitian pada wanita di sanggar senam RITA Pati). Developmental and Clinical Psychology, 2(2), 44-49. Diakses dari https://journal.unnes.ac.id/sju/index.php/dcp/ article/download/2575/2365

Junaidi. (2015). Hubungan lingkungan kerja dan beban kerja dengan stres pegawai di badan pemberdayaan perempuan dan keluarga berencana. Promotif, 4 (2), 115-121. Diakses dari https://www.scribd.com/doc/260681291/6JURNAL JUNAIDI-STRES-KERJA-pdf.

National Heart, Lung, and Blood Institute. (2012). Anemia. Diakses dari https://www.nhlbi. nih.gov/health/health-topics/topics/anemia/ livingwith.

NEDC (National Eating Disorders Collaboration). (2016). Body image. Diakses dari http://www. nedc.com.au/files/logos/0638_NEDC_FS_BI_ v4.pdf.

Noviawati, E. (2015). Hubungan asupan zat besi dengan kejadian anemia pada mahasiswi PSPD angkatan 2009-2011. (Skripsi, UIN Syarif Hidayatullah, Jakarta). Diakses dari http://repository.uinjkt.ac.id/dspace/ handle/123456789/26377.

Ozier, A.D., Kendrick, O.W., Knol,L.L., Leeper,J.D., \& Perko, M. (2007). The EADES (Eating and Appraisal Due to Emotions and Stress) questionnaire: Development and validation. Journal of The American Dietetic Association, 107(4), 619-628.

Patricia, N.L. (2014). Pengaruh gaya hidup hedonisme terhadap perilaku konsumtif pada pramugari maskapai penerbangan ' $\mathrm{X}$ '. Jurnal Psikologi 12(1), 10-17. Diakses dari http:// ejurnal.esaunggul.ac.id/index.php/psiko/article/ view/1458/1327.

Pusporiny, V. (2016). Gaya hidup pramugari : Gaya hidup konsumtif \& perilaku konsumtif pada pramugari maskapai penerbangan Garuda Indonesia (Skripsi, Universitas Airlangga, Surabaya). Diakses dari http://repository.unair. ac.id/45395/2/Full\%20Text.pdf.

Putri, S.R. (2014). Hubungan citra tubuh terhadap status gizi pramugari PT. Garuda Indonesia 
Periode Januari 2014 (Skripsi, Universitas Pembangunan Nasional Veteran, Jakarta). Diakses dari http://library.upnvj.ac.id/index. php? $\mathrm{p}=$ show_detail\&id=13797.

Sary, R.N., Gathmyr, D., Siagian, C.M, \& Basuki, B. (2014). Eating habit and other factors related to anemia in civil female flight attendant in Indonesia. Health Science Journal of Indonesia, 5(2), 67-72. Diakses dari http://ejournal. litbang.depkes.go.id/index.php/HSJI/article/ view/3592/4454.

Setyaningsih, W. (2015). Konsumsi besi folat, tingkat kecukupan energi dan zat besi berhubungan dengan kejadian anemia ibu hamil di Kabupaten
Jember. Public Health and Preventive Medicine Archive, 3(1), 4-12. Diakses https://media. neliti.com/media/publications/21485-ID-ironfolate-consumption-energy-dan-iron-adequacylevel-associated-with-prevalenc.pdf

Sugiyono. (2009). Metode penelitian bisnis (pendekatan kuantitatif, kualitatif, dan $R \& D$ ). Bandung: Alfabeta.

WHO. (2011). Haemoglobin concentration for the diagnosis of anemia and assessment of severity. Diakses dari http://apps.who.int/iris/ bitstream/10665/85839/3/WHO_NMH_NHD_ MNM_11.1_eng.pdf?ua=1. 